\title{
Ethnic processes in post-communist Europe during the 1990s
}

\author{
VLADIMÍR VOJTĚCH \\ Charles University in Prague, Faculty of Science, \\ Department of Social Geography and Regional Development
}

\begin{abstract}
In this paper, the author assesses and explains changes in ethnic composition that occurred in the postcommunist countries of Europe and the Caucasus during the 1990s. Quantitative as well as qualitative aspects of ethno-demographic changes are emphasized. Points of departure are the censuses of 1989/1992 and 1999/2004, and alternatively, the estimates of international organizations. Assessment is carried out at the state and regional levels. The current ethnic composition of post-communist Europe is the result of three ethnic processes. Homogenization concerns those states with a lower initial degree of ethnic homogeneity. Polarization (the formation of two or more ethnically dissimilar entities within one state) was also a prevalent outcome. Those processes were more powerful in war-stricken areas due to forced migrations and ethnic cleansing. Natural increase, governmental ethnic policies and the social atmosphere played an important role in the establishment of peaceful conditions. Conversely, countries that are ethnically homogeneous to a high degree recorded a decrease in their level of ethnic homogeneity. This was caused not only by immigration, but also by subjective factors.
\end{abstract}

Key words: nationalism, titular nation, ethnic processes, ethnic homogeneity, census

\section{Introduction}

The sudden downfall of communism in Central, Eastern and South-Eastern Europe between the years 1989 and 1991 brought a sharp expansion of nationalism. However, nationalism had been in existence long before then. It was linked with emancipation of the local nations in the $19^{\text {th }}$ century. During the communist era, nationalism served as an ideological opposite. The local nations were reminded of subjugation by the Soviet Union and understood communism as an imported, alien ideology. The newest phase of expansion of nationalism began in connection with the fall of the communist regimes (Hroch 1996; Pearson 1995). According to Fukuyama (2002), Huntington (2001) and Yamskov (1999) the expansion of nationalism in the 1990s resulted from the rejection of Marxist ideology. This was connected with disillusionment and deprivation. The resultant ideological void was filled in by a resurgence of traditional 
cultural identity. In accordance with other scholars (MacFarlane 1997; Malek 2006), elites converted from communism to nationalism in order to maintain their power and profits.

Nationalistic passion quickly softened in the highly ethnically homogeneous countries (e.g. Czechia, Poland, Slovenia). On the other hand, nationalistic expressions persisted for a long time in countries with large territorially concentrated minorities. Moreover, those expressions were nourished by growing inter-ethnic cleavages (Hroch 1996). A similar case can be found in ethnically homogeneous countries which create numerous minorities abroad (e.g. Hungary, Armenia). Those cases were either handled peacefully or grew into armed conflicts. The latter changed the spatial distribution of nations and significantly disrupted inter-ethnic relations. The governmental response to multiethnicity also influenced integration into the EU and NATO. Countries which responded peacefully or moderated their confrontational rhetoric (e.g. the Baltics, Slovakia) are today members of the EU and NATO. However, violently responding countries found themselves isolated, and their attachment to European institutions is currently problematic (e.g. Croatia, Serbia). It is otherwise necessary to know that nationalism was not a foundation stone of some conflicts. For example, the conflicts in Transnistria, Abkhazia and Chechnya had an economic and strategic genesis from the start.

\section{Objectives and Hypotheses}

The scope of study of this paper is an evaluation of the ethnic processes that occurred in post-communist countries after the fall of the Iron Curtain. Its objective is to detect the impact of the new conditions on the expansion of nationalism and separatism. That affected the subsequent course of events, which are assessed in the former Yugoslavia, Bulgaria, Romania, Slovakia, and in the European and Caucasian republics of the former Soviet Union.

Expansion of nationalism was significant for changes of majority's and minorities' behaviour. On that account the first hypothesis posits ethnic homogenization as a dominant process in the countries studied. The homogenization could be either "hard" or "soft". The "hard" form encompasses results of war, ethnic cleansing and forced migrations. It concerns not only war-stricken areas but also territories affected by an inflow of displaced people of the same ethnic origin. The "soft" form of homogenization includes the emigration of minorities or originally governing nations due to an unfavourable social climate.

The second hypothesis verifies Tesařs (2007) declaration that ethnic conflicts predominantly occur on the periphery. He argues that economic underdevelopment reflects, for example, the lower level of education of minority members. That implies a lesser ability to compete for economic resources, and consequently leads to frustration. And all of that can result in insurgency and armed conflict. Let us presuppose - together with Tesař (2007) - a higher number of ethnic conflicts on the periphery, and a higher level of ethnic homogenization during the assessed era. Viceversa, the historical cores of states could be almost exclusively inhabited by members of the titular (state) nation, and thus exhibit a lower level of ethnic homogenization. 
The spatial distribution of minorities, how it changes, and the evolution of interethnic relations are assessed only in post-communist countries with a significant representation of ethnic minorities. The highly ethnically homogeneous countries Czechia, Poland, Hungary, Albania and Armenia - are not assessed. In the case of Czechia and Poland, ethnic and political boundaries have been congruent since World War II. Hungary, Albania and Armenia are core areas of residence of their titular nations with large number of ethnic kinsmen abroad. Belarus and Lithuania are also excluded. For Belarus, thanks to the low ethnic consciousness of the Byelorussians, the Russian-Byelorussian union and having Russian as an official language. Lithuania's exclusion stems from its lesser problematic relationship to the Russian minority. Because it has an 80 percent Lithuanian and only 6 percent Russian population (2001 census), the latter got Lithuanian citizenship automatically when it declared its independence. Therefore Lithuania was under less pressure from the EU in comparison to Latvia and Estonia.

Periods which saw the greatest changes in the spatial distribution of nations or in inter-ethnic relations are studied. The 1990s are predominant. Data come from censuses performed by state statistical institutions. In case of the absence of census data, estimates from international organizations (e.g. OSCE, UN) were used. Regional level data were a foundation stone for quantitative analysis. In case of war-stricken areas data quality is questionable. Authorities try to mask the exodus of populations or the resettling of a large number of refugees, and indicate stabilization of a particular region (Radvanyi, Muduyev 2007). Problems with the population statistics of separatist states include, in particular, the disputable delimitation of borders and non-standardized methods of data collection (Rowland 2008).

Relativity, subjectivity and the mutability of ethnic affiliation have to be considered when working with ethnic composition data. In case of some culturally divided countries, ethnic affiliation could be derived from religious affiliation. For instance, the Christian Albanians in Macedonia identify themselves as Macedonians and the Muslim Slavs as Albanians. The Romanies are another typical example. They use ethnic mimicry - taking on the identity of the majority to be safe. Because of the importance of other social categories for the Romanies, their changeable ethnic mimicry is a serious obstacle to the study of changes in the spatial distribution of minorities.

The level of ethnic homogeneity of the studied states and regions was measured by Piasecki's (1964) ethnic homogeneity index $I_{h}$ :

$$
I_{h}=\sum_{i=\mathrm{i}}^{\mathrm{n}} \frac{e_{i}^{2}}{P_{2}},
$$

where $e$ stands for the number of members of the $i$-nation and $P$ for the population size of the assessed territory. The marginal values of the index are 0 (absolute ethnic heterogeneity) and 1 (absolute ethnic homogeneity). Auxiliary measures for studying the spatial distribution of nations could be standard deviation (weighed by population) and variation coefficient. Because of countries' different population 
sizes and their various number of regions, the measures of variability cannot be compared. Those measures could only give precision to the ethnic homogeneity index. The growth of their values could indicate the ethnic polarization of a particular country. Nevertheless, it is very difficult to explain them, especially in the case of deeply ethnically polarized countries with vigorous and vital minorities (e.g. Serbia, Macedonia and its Albanians). In such cases, measures of variability show mutually opposing values.

The entropy index is an appropriate alternative. It measures the orderliness of ethnic composition in regions (Massey, Denton 1988). It is first necessary to calculate the state's and region's entropy $E$.

$$
E=P \cdot \log \left(\frac{1}{P}\right)+(1-P) \cdot \log \left(\frac{1}{1-P}\right),
$$

where $P$ stands for the ratio of the titular (state) nation in the state's or region's population. Next, the entropy index $H$ has to be calculated.

$$
H=\sum_{i=\mathrm{i}}^{\mathrm{n}} \frac{\mathrm{t}_{i} \cdot\left(\mathrm{E}-\mathrm{E}_{i}\right)}{E \cdot T},
$$

where $E$ stands for the state's entropy, $E_{i}$ for the region's entropy, $t_{i}$ for the region's population and $T$ for the state's population. The entropy index $H$ oscillates between 0 (all regions have identical ethnic composition) and 1 (each region is entirely inhabited by one dissimilar nation).

Correlation and regression analyses proved to be the most comprehensible. The regression monitors two relationships:

a) between the level of ethnic homogeneity at the beginning of the 1990s (regressor) and its change during the 1990s (response variable),

b) between the change of the ratio of the titular (state) nation in the population (regressor) and the change of the level of ethnic homogeneity during the 1990s (response variable).

Spearman's coefficient $r$ was used for the correlation analysis, because a normal distribution of the variables studied cannot be presupposed in many countries.

$$
r=1-\frac{6}{n \cdot\left(n^{2}-1\right)} \sum_{i=\mathrm{i}}^{\mathrm{n}}\left(R_{i}-Q_{i}\right)^{2},
$$

where $n$ stands for the count of regions. $R_{i}$ symbolizes numerical rank of $i$-region's variable $X$ and $Q_{i}$ numerical rank of $i$-region's variable $Y$. Values of the coefficient $r$ oscillate between -1 and 1 . Those marginal values stand for a strong negative (the former) or a positive (the latter) correlation. The values around zero stand for low or no correlation. When we look at the latter above-mentioned relationship, strong positive correlation indicates ethnic homogenization or heterogenization. Lower values indicate ethnic polarization. The regression analysis and additional correlations are therefore necessary for further contemplation about those processes. The statistical significance of all correlations is proven at a 95 percent confidence level. 


\section{Ethnicity, Ethnic Conflicts, Nationalism}

Ethnicity and nationalism are interconnected terms. The different position of nations - most frequently among majorities and minorities - is a foundation stone of nationalistic motivation. Multifarious scholars have their own views of ethnic topics.

\subsection{Ethnicity}

Smith (1998) defines ethnie (or ethnic community) by five features - (1) shared myths about a unique collective origin, (2) territory inhabited by a particular ethnie that identifies itself with territory, (3) a sense of solidarity to the ethnic kinsmen (called co-ethnies by Smith for short), (4) shared cultural components (unique language) and symbols (hymns, celebrations, habits, holy places, dead heroes, etc.), (5) a collective name (ethnonym). Those features distinguish one ethnie from another and give it a sense of exclusivity. Tesař (2007) adds that the identity of less-developed ethnies is shaped by antinomies - what a particular group is not. Krejčí (2002) adds to the linguistic attribute of ethnicity also a religious one. Religion could become an important feature of ethnicity at the fault lines between different civilizations (Huntington 2001). The Southern Slavs having a Serbo-Croat language - divided into Orthodox Serbs, Catholic Croats and Muslim Bosniaks - are the model. In that case, historical national territories and their divisions are very important symbols. They represent the cradle of a nation or the outermost outpost of civilization (Huntington 2002; Smith 1998). Smith (1998) and Connor (1994) especially differentiate between the objective and subjective criteria of ethnicity. The objective elements include language, religion and inhabited territory. Subjective (emotive, psychological) elements include the consciousness of people about appurtenance to the particular ethnic group, its uniqueness, common historical experience, common solidarity and common future. Furthermore, reality (or rationality) does not perform a prime role whereas the subconscious, emotions and mythology do (Connor 1994).

Nederveen Pieterse (1995) distinguishes three grades of ethnicity - (1) ethnic category or group, (2) ethnic community or ethnicity and (3) ethnonationalism. Ethnic category (group) is defined by objective cultural features, frequently from the outside. Those features then serve to give the ethnic community its own consciousness about internal cohesion, solidarity and separation from other entities. Several ethnic categories (groups) could exist in one ethnic community (Žaloudek 2004). A highly developed political consciousness as well as a strong sense of mutual cohesion and solidarity are the main features of the ethnonational formation (Tesar 2007). Nonetheless, ethnicity (or ethnie) and nation could be substituted freely (Tesař 2007). According to Gellner (1993) two people belong to the same ethnie (or nation) if one recognizes another as a member of the same ethnie.

Ethnicity is a relative phenomenon (Gellner 1993; Nederveen Pieterse 1997; Tesař 2007). Human beings learn it during the socialization process. High culture, whose foundations are literacy and standardized education, serves to connect a nation (Gellner 1993). High culture permeates the whole nation and is guaranteed or secured officially. It allows universally educated individuals to interact and be geographically as well as 
socially mobile. Moreover, individuals identify themselves with their acquired high culture. Therefore ethnicity is a learned image in the human mind. This image can be affected by many variables, such as historical heritage, socio-economic and political shifts, changes in centre-periphery relations, etc. (Kelman 1997). Affairs such as reconstruction of ethnic identity, the selection of appropriate myths, and the choice of suitable people for incorporation into the group identity are related to these important phenomena. Thus ethnicity has to ensure an identity congruent with the requirements of individuals (Tesař 2007). At the same time, the interests, opportunities and necessities of ethnic elites must not be omitted (Kelman 1997).

\subsection{Ethnic Conflicts}

According to Harvey (2000) ethnic rivalry is the main source of violence and wars in the world after the Cold War. The tangible denominators of those are large territorially concentrated minorities, the ethnic division of a country multiplied by political and economic problems, a government lacking institutional capabilities of stopping the conflict peacefully, the absence of a political and civic culture aiming to resolve and moderate the conflict efficiently, highly divided political loyalties, and political elites who attempt to maintain their power. Harvey (2000) adds that ethnic conflicts tend to spread out behind borders.

A lot of theories explain ethnic violence. Primordialism, instrumentalism, the modernization theory, the internal colonization model and the inter-ethnic competition model. According to primordialism, ethnic identity is strongly nursed emotionally and given for life. Ethnic conflict is therefore unavoidable and arises from human nature (Tesař 2007). Ethnic conflicts are explained by the efforts of a particular nation to survive, by the fear of other nations and by mistrust or hatred of them. Harvey (2000) explains the wars in the Balkans and Transcaucasus by this theory. Demographic balance was disrupted in those areas through the demographic vigour of the local Muslim nations. The local Christian nations perceived that as a threat and tried to ethnically cleanse their territory. Primordialism also relates to ethnic nepotism (Vanhanen 1999), i.e. the inclination to back up one's own ethnic relatives (or co-ethnies abroad) in spite of the frequently high cost. That secures the existence of a particular nation. According to Vanhanen (1999), a strong ethnic division implies intense ethnic nepotism. This is the common denominator of ethnic conflicts.

Instrumentalism says that elites use ethnicity to maintain their power and status through mass mobilization. Development of democratic participation threatens the reigning authoritarian elites in democratizing societies. In order to eliminate risk and obtain support from the population they play on its ethnic consciousness (MacFarlane 1997). Ethnic conflict is therefore the result of private interests and power manipulation. The national leaders of Yugoslav or Soviet ethnic units are suitable examples. Those leaders asserted themselves in situations with a given formal base, such as a republic or an autonomous unit, whereas leaders of nations without autonomous status could not (MacFarlane 1997; Tesař 2007).

The modernization theory (alternatively called the assimilation model) perceives the countryside as a base of religious consciousness, lacking in tolerance. The 
significance of ethnic identity decreases with modernization (urbanization, industrialization). Differences arising from class affiliation and politico-economic interests appear to be the chief momentum (Dostál 1998).

According to the internal colonization model (alternatively known as cultural division of labour), ethnic solidarity is the rational response of an ethnically distinct periphery to exploitation by the centre, which is inhabited by the dominant nation. Ethnic mobilization arises when members of the dominant nation hold higher occupations and control economic and political resources, while the peripheral group does not. Thus class and ethnic differentiations correlate. The higher disadvantage of the periphery implies a greater possibility of ethnic aspirations emerging against the centre (Dostál 1998). Conflicts arising from the cultural division of labour are very violent and look like social revolution. The conflicts in Kosovo or Bosnia-Herzegovina are good examples (Tesar 2007). The cultural division of labour comes into view in the Baltics. The non-citizens (Russians) have limited access to the labour market and lower social status due to their ignorance of the official language (Pettai, Hallik 2002).

The inter-ethnic competition model is an inversion of the modernization theory. In accordance with that model, the increase in inter-ethnic contacts resulting from modernization implies the growth of ethnic consciousness and intolerance (Tesar 2007). Ethnic peripheries originate during the modernization process. Their elites feel relative deprivation owing to limited access to the power sector of the state. Strong nivelization of regional disparities did not manage to resolve that feeling during the communist era. Members of the individual nations contend with each other for the same occupational places, political influence, etc. Ethnic solidarity is a relevant component in any case. Therefore nationalistic movements referred to ethnically defined interests and promised sovereignty in order to get public support (Dostál 1998). An ethnic majority exhibits the biggest decrease in tolerance because numerical dominance could also imply economic, cultural and political dominance (Tesař 2007). According to Dostál (1993; 1998), the inter-ethnic competition model explains the dissolution of the former socialist federations. On the other hand, Connor (1994) discourses on the independence of ethnic conflicts and nationalism from economic indicators. He stresses cultural deprivation and resistance to the supremacy of the alien nation. The Slovenes and Croats in the former Yugoslavia or the Basques and Catalonians in Spain are appropriate examples. Those nations show (have shown) higher living standards than the dominant nation. Connor (1994) adds, however, that economic argumentation could be a catalyst of ethnic tensions.

Plenty of other views on ethnic conflicts exist. Fukuyama (2002) says that liberal democracy is the final version of government. Expansions of nationalism, ethnic fractionalization and ethnic conflicts are only a painful prologue to the subsequent democratization. Huntington's (2001) view is opposite. Conflicts between entities from different civilizations will occur after the Cold War. The worth of Huntington's paper has been devalued because of its inter-civilizational look at all conflicts between entities with different religions. But the role of religion could only be marginal, as in the case of cleavages among the Baltic nations and Russians (virtually Moscow), between the Romanians and Transylvanian Hungarians, and between the Armenians and Azeris. Those conflicts are historical or purely ethnic in origin. 
Nationalism is a political idea which originally stated that ethnic and political entities ought to be congruent. Nationalist feelings therefore become spite, if that congruency is not realized, or else delight in filling that congruency. The cultural dissimilarity of rulers and the subjugated is negative (Gellner 1993). The worst case comes if the subjugated entity creates a compact population within the scope of a state, or is split up into more states (e.g. the Yugoslav Albanians, Basques, Kurds). The opposite case, when one cultural entity has more states - such as the Arabs, Serbs or Albanians - is not negative (Gellner 1993). State elites are against their unification frequently because they could lose leading posts.

Nationalism is related to modernization, when the uprooted rural population underwent frustration and disillusionment. For this reason, the original social order was replaced by a culture and language that created a new frame for human thinking (Gellner 1993). Class membership competed with cultural (ethnic) identity, but permanent class struggle could induce civil war. That is why an atomised society was covered by cultural identity and by a strong state on that basis (Arendt 1996). According to Gellner (1993), modern industrial society requires cultural homogeneity, while rural agrarian or industrializing society does not. Modern society is marked by high fluidity and contingency. Therefore their members have to receive an all-purpose education - i.e. high culture - delivered by the modern state via a centralized educational system. Nations are created by nationalism, and the reverse is, in accordance with Gellner (1993), impossible. Nationalism comes from local folk culture transformed into high culture. Suppression of local folk culture by an alien high culture results in the emergence of nationalism. The result is a national liberation movement which struggles for an independent state with its own high culture. In the opposite case, the members of the oppressed nation have to compete with better qualified members of the dominant nation for posts and profits. Thus the nation is not able to survive without its motherly rind - its own state. On the other hand, primordialist Smith (1998) argues for no direct connection between modernity and nationalism. According to Fukuyama (2002), the modernisation of nationalism lies in replacing subordination by mutual and equal recognition. However, this recognition pertains only to members of a particular nation.

Ethnic tensions are intensified with the focus on an all-purpose educational system protected by the state. Therefore many states emphasize territorial integrity instead of cultural homogeneity (Smith 1998). The result is civic (liberal, political) nationalism. The unity of the population with regard to some values, visions and symbols is objective. It is inclusive nationalism oriented toward the state. State affiliation (ius soli) is the main principle in lieu of ethnicity. The United Kingdom, France and Spain are excellent examples. Identification of all citizens with the state is an indispensable condition (Fňukal 2001; Johnson 2002). Civic nationalism has problems too. Part of the citizenry can approach non-identification with the state, or with the state's efforts to assimilate different cultural entities. Romania's effort to assimilate the Transylvanian Hungarians and Azerbaijan's effort to assimilate the Talyshs and Lezgins are two examples. Another suitable example is the nationalism of the non-Russians in the Soviet Union. 
Nationalism of an ethnocultural entity (alternatively, organic nationalism) is the opposite of civic nationalism. The fundamental principle is that membership in a particular nation is inherited from ancestors, and passed on by blood (ius sanguinis). Long-term residence within the state's territory is irrelevant. The nation is therefore understood primordially (Smith 1998). We can distinguish between German-type nationalism and ethnonationalism (Fňukal 2001; Johnson 2002). The former stresses the role of language, but not religion. The latter stresses religion as well.

The type of nationalism, implying treatment of minorities by the state, is written in the constitution. The raison d'etre of the state is justified there. In the case of civic nationalism, the state ought to be in the possession of all citizens, regardless of their ethnicity. "We, citizens of the state..." is a common introductory thesis of constitutions, although the practise is often diverse. In the case of cultural nationalism, the titular (state) nation is the exclusive holder of the state. Its role is exalted in the constitution. "Croatia is the state of the Croats..." is an exemplary constitutional thesis. The formula that the majority has to respect minorities as constituent parts of the state is good practise. According to Smith (1998), the revival of cultural nationalism is a consequence of the decline of civic nationalism. Yugoslavia at the turn of the 1980s and 1990s is representative of this.

Nationalism was seen as an anachronism during the communist era. Internationalism which proclaimed the unity of the world's proletariat and trivialized ethnic consciousness was the prime ideology (Smith 1998, Yamskov 1991). Ethnic differences were also inhibited by a bipolar world order. The Eastern version of modernization was marked by non-democratic and forcible control of ethnic aspirations, suppression of freedom of speech, etc. This resulted in an expansion of ethnic consciousness, the resurrection of historical injustices, and the expansion of nationalism and secessionism. The outcome was centrifugal forces which brought about the dissolution of socialist federations. The historical disgrace of the Marxist ideology and of communist parties was also an important variable. Mistrust of minority nations within the further duration of federations was the result. Furthermore, federated entities were established on an ethnic basis, thus members of the titular nation perceived themselves as exclusive owners of their homeland. This idea was seized by ethnic elites in order to get electoral support in the first democratic elections (Dostál 1998). Pearson (1995) argues that the expansion of nationalism before 1989 was influenced, not only by the economic situation and ill-treatment of minorities, but also by the transformation of the geopolitical climate in some Eastern European countries. In the first case, the original majorities became minorities in parts of their territory due to the high birth rate of another nation (the Serbs in Bosnia-Herzegovina). In the second case, the majority of the titular nation was jeopardized by massive immigration (the Latvians and Estonians in their republics). Expansion of nationalism at the turn of the 1980s and 1990s is also connected with anti-Russian attitudes (Pearson 1995). Eastern European nations were under Soviet political, economic and cultural domination. According to Hroch (1996), the objectives of Eastern European nationalism at the end of the 1980s were similar to those of nationalism in the $19^{\text {th }}$ century. Their requirements were cultural (national culture, the strengthening of national language), social (division of incomes, fiscal autonomy, full social structure) and political (independence). The 
expansion of nationalism in the post-Soviet and post-Yugoslav space arose because the original idea of nationalism (congruency of cultural and political borders) was not fulfilled (Hroch 1996).

\section{Ethnic composition, its changes and a comparison of ethnic processes}

Ethnic and religious compositions constitute a stable factor in the development of states. However, they shift in the case of influential socio-economic and geopolitical changes. Disintegration of once multi-ethnic states - which were often preserved artificially - is accompanied by efforts of the successor states to achieve ethnic homogeneity (see Tab. 1), and by the new minorities to achieve self-determination. These are often ended by conflicts of various forms. They vary from confrontational government rhetoric and forced assimilation to armed conflict accompanied by the forced displacement of populations. The peaceful dissolution of Czechoslovakia and relatively calm disintegration of the Soviet Union were accompanied by the Yugoslav wars. Significant inter-ethnic tensions also existed in other post-communist countries.

The geopolitical transition of the post-communist countries was an important variable in the change of their ethnic composition. The proper treatment of minorities was linked to countries' efforts to speedily join the EU and NATO. Therefore minorities are entitled to study their language in public schools, form their own cultural and social organizations, and be included in administrative and representative bodies. In several countries, minorities can also use their languages in regional official contacts. But many countries have logistic-financial obstacles to implementing all those rights. In certain post-communist countries, what is pronounced and its inverse exist simultaneously. In spite of their constitution, they discriminate against minorities in access to public sector employment, obstruct the homecoming of minority refugees, etc. Countries which experienced armed conflict in the 1990s are fitting examples. Croatia alone tries to progress in that domain because of its serious-minded goal of joining the EU. The most problematic situation in relation to minorities prevails in ethnically polarized countries with mutually unfriendly nations.

Table 1 Ethnic composition of the studied post-communist countries in the years 1989/1992 and 1999/2006

\begin{tabular}{|c|c|c|c|c|}
\hline \multirow{2}{*}{ Country } & \multirow{2}{*}{$\begin{array}{c}\text { Year } \\
\text { of census }\end{array}$} & \multicolumn{3}{|c|}{ Ethnic composition (percent) } \\
\hline & & $1^{\text {st }}$ nation & $2^{\text {nd }}$ nation & $3^{\text {rd }}$ nation \\
\hline \multirow{2}{*}{$\begin{array}{l}\text { Azerbaijan } \\
\text { (N.-Karabakh incl.) }\end{array}$} & 1989 & Azeris 82.7 & Russians 5.6 & Armenians 5.6 \\
\hline & $1999 / 2005$ & Azeris 90.4 & Lezgins 2.2 & Russians 1.8 \\
\hline \multirow{2}{*}{ Croatia } & 1991 & Croats 78.1 & Serbs 12.2 & Bosniaks 0.9 \\
\hline & 2001 & Croats 89.6 & Serbs 4.5 & Bosniaks 0.5 \\
\hline \multirow{2}{*}{ Romania } & 1977 & Romanians 88.1 & Hungarians 7.9 & Romanies 1.1 \\
\hline & 2002 & Romanians 89.5 & Hungarians 6.6 & Romanies 2.5 \\
\hline
\end{tabular}




\begin{tabular}{|c|c|c|c|c|}
\hline \multirow{2}{*}{ Slovakia } & 1991 & Slovaks 85.7 & Hungarians 10.8 & Romanies 1.4 \\
\hline & 2001 & Slovaks 85.8 & Hungarians 9.7 & Romanies 1.7 \\
\hline \multirow{2}{*}{ Bulgaria } & 1992 & Bulgarians 86.0 & Turks 9.7 & Romanies 3.4 \\
\hline & 2001 & Bulgarians 83.9 & Turks 9.4 & Romanies 4.7 \\
\hline \multirow{2}{*}{ Slovenia } & 1991 & Slovenes 87.8 & Croats 2.8 & Serbs 2.4 \\
\hline & 2002 & Slovenes 83.1 & Serbs 2.0 & Croats 1.8 \\
\hline \multirow{2}{*}{ Russia } & 1989 & Russians 81.5 & Tatars 3.8 & Ukrainians 3.0 \\
\hline & 2002 & Russians 79.8 & Tatars 3.8 & Ukrainians 2.0 \\
\hline \multirow{2}{*}{$\begin{array}{l}\text { Georgia (Abkhazia } \\
\& \text { S. Ossetia incl.) }\end{array}$} & 1989 & Georgians 70.1 & Armenians 8.1 & Russians 6.3 \\
\hline & $2002 / 2003$ & Georgians 79.8 & Azeris 6.1 & Armenians 5.3 \\
\hline \multirow{2}{*}{ the Ukraine } & 1989 & Ukrainians 72.7 & Russians 22.1 & Byelorussians 0.9 \\
\hline & 2001 & Ukrainians 77.8 & Russians 17.3 & Byelorussians 0.6 \\
\hline \multirow{2}{*}{$\begin{array}{l}\text { Moldova } \\
\text { (Transnistria incl.) }\end{array}$} & 1989 & Moldovans 64.5 & Ukrainians 13.8 & Russians 13.0 \\
\hline & 2004 & Moldovans 71.5 & Ukrainians 11.2 & Russians 9.4 \\
\hline \multirow{2}{*}{ Estonia } & 1989 & Estonians 61.5 & Russians 30.3 & \\
\hline & 2000 & Estonians 67.9 & Russians 25.6 & \\
\hline \multirow{2}{*}{ Macedonia } & 1991 & Macedonians 65.3 & Albanians 21.7 & Turks 3.8 \\
\hline & 2002 & Macedonians 64.2 & Albanians 25.2 & Turks 3.9 \\
\hline \multirow{2}{*}{$\begin{array}{l}\text { Serbia } \\
\text { (Kosovo incl.) }\end{array}$} & 1991 & Serbs 65.9 & Albanians 17.1 & Hungarians 3.5 \\
\hline & $2000 / 2006$ & Serbs 62.7 & Albanians 24.1 & Hungarians 2.9 \\
\hline \multirow{2}{*}{ Latvia } & 1989 & Latvians 52.0 & Russians 34.0 & Byelorussians 4.5 \\
\hline & 2000 & Latvians 57.7 & Russians 29.6 & Byelorussians 4.1 \\
\hline \multirow{2}{*}{$\begin{array}{l}\text { Bosnia- } \\
\text { Herzegovina }\end{array}$} & 1991 & Bosniaks 43.5 & Serbs 31.2 & Croats 17.4 \\
\hline & 2002 & Bosniaks 53.1 & Serbs 28.2 & Croats 16.5 \\
\hline \multirow{2}{*}{ Montenegro } & 1991 & Montenegrins 61.9 & Bosniaks 14.6 & Serbs 9.3 \\
\hline & 2003 & Montenegrins 43.2 & Serbs 32.0 & Bosniaks 11.7 \\
\hline
\end{tabular}

Source: The statistical institutes of the countries studied

Values of the ethnic homogeneity index enable us to describe elementary changes in the ethnic composition of the countries studied. Romania, Slovenia, Slovakia and Bulgaria were the most homogeneous countries at the beginning of the 1990s, while Bosnia-Herzegovina, Latvia and Moldova were the most heterogeneous. That ranking changed thanks to inter-ethnic conflicts and intolerant ethnic politics during the 1990s. The war-stricken countries showed the biggest step-up. Ethnic conflicts were 
accompanied by pogroms, forced migrations and ethnic cleansing. The demographic vigour of the state nation and minorities, governmental ethnic politics and the social atmosphere were the main factors determining peaceful conditions. Conversely, countries with a higher starting level of ethnic homogeneity (i.e. Slovenia, Slovakia, Bulgaria; outside the studied countries also Czechia, Hungary and Poland) displayed ethnic heterogenization. Immigration and subjective factors (change of ethnic selfidentification) were their main components. The latter factor also caused the ethnic heterogenization of Montenegro (historical oscillation between Serb and Montenegrin identities).

Table 2 Ethnic configuration of the studied post-communist countries

\begin{tabular}{|c|c|c|c|c|}
\hline \multirow{2}{*}{ Country } & \multicolumn{2}{|c|}{ Ethnic homogeneity index } & \multicolumn{2}{|c|}{ Entropy index } \\
\hline & $1989 / 1992$ & $1999 / 2006$ & $1989 / 1992$ & $1999 / 2006$ \\
\hline Azerbaijan (N.-Karabakh incl.) & 0.69 & 0.82 & 0.055 & 0.133 \\
\hline Croatia & 0.63 & 0.81 & 0.099 & 0.074 \\
\hline Romania* & 0.81 & 0.81 & 0.302 & 0.271 \\
\hline Slovakia & 0.75 & 0.75 & 0.298 & 0.267 \\
\hline Bulgaria & 0.75 & 0.72 & 0.150 & 0.119 \\
\hline Slovenia & 0.78 & 0.70 & 0.024 & 0.011 \\
\hline Russia - European part & 0.69 & 0.66 & 0.251 & 0.279 \\
\hline Georgia (Abkhazia, S. Ossetia incl.) & 0.51 & 0.65 & 0.044 & 0.118 \\
\hline the Ukraine & 0.58 & 0.64 & 0.148 & 0.181 \\
\hline Moldova (Transnistria incl.) & 0.46 & 0.54 & 0.036 & 0.095 \\
\hline Estonia & 0.48 & 0.53 & 0.222 & 0.250 \\
\hline Macedonia & 0.48 & 0.48 & 0.239 & 0.248 \\
\hline Serbia (Kosovo incl.) & 0.48 & 0.46 & 0.396 & 0.513 \\
\hline Latvia & 0.39 & 0.43 & 0.123 & 0.133 \\
\hline Bosnia-Herzegovina & 0.32 & 0.39 & 0.039 & 0.276 \\
\hline Montenegro & 0.42 & 0.31 & 0.193 & 0.143 \\
\hline
\end{tabular}

* Romania - census 1977: ethnic homogeneity index 0.78; entropy index 0.333

Source: Computation by the author from the census data provided by the statistical institutes of the countries studied

Employing the ethnic homogeneity index is misleading at the state level. That index is able to distinguish only two processes - homogenization vs. heterogenization. But the entropy index also reveals a third relevant process - ethnic polarization - because it measures the dissimilarity of regional ethnic compositions. The entropy index decreases during the homogenization or heterogenization processes because of the 
diminution of differences among the ethnic structures of regions and state. Vice versa, differences among those structures increase during ethnic polarization. This is supported by the growth of the entropy index (see Tab. 2). Bosnia-Herzegovina (also the Bosniak-Croat Federation), Serbia, Macedonia, Moldova, Georgia and Azerbaijan are the apposite examples. Ethnic polarization is also sustained by regional values of the ethnic homogeneity index (see Tab. 3). It is also true that war-stricken countries demonstrated a higher rate of ethnic polarization.

Table 3 Serbia as an example of an ethnically polarized country

\begin{tabular}{|l|c|c|c|c|c|c|}
\hline \multirow{2}{*}{ Unit } & \multirow{2}{*}{ Year } & \multicolumn{4}{|c|}{ Ethnic composition (percent) } & $\begin{array}{c}\text { Ethnic } \\
\text { homogeneity } \\
\text { index }\end{array}$ \\
\cline { 3 - 7 } & & Serbs & Albanians & Hungarians & Others & 0.78 \\
\hline \multirow{2}{*}{$\begin{array}{l}\text { Central } \\
\text { Serbia }\end{array}$} & 1991 & 87.9 & 1.3 & 0.1 & 10.7 & 0.81 \\
\cline { 2 - 7 } & 2002 & 89.5 & 1.1 & 0.1 & 9.3 & 0.42 \\
\hline \multirow{3}{*}{\begin{tabular}{l} 
Vojvodina \\
\cline { 3 - 7 }
\end{tabular}} & 1991 & 56.8 & 0.1 & 16.9 & 26.2 & 0.49 \\
\cline { 2 - 7 } Kosovo & 2002 & 65.0 & 0.1 & 14.3 & 20.6 & 0.68 \\
\cline { 2 - 7 } & $2000 / 06$ & 4.8 & 90.8 & 0.0 & 4.4 & 0.83 \\
\hline \multirow{2}{*}{$\begin{array}{l}\text { Serbia } \\
\text { in total }\end{array}$} & 1991 & 65.9 & 17.1 & 3.5 & 13.5 & 0.48 \\
\cline { 2 - 7 } & $2000 / 06$ & 62.7 & 24.1 & 2.9 & 10.3 & 0.46 \\
\hline
\end{tabular}

Sources: Statistical Office of the Republic of Serbia, Organization for Security and Co-operation in Europe

The correlation between the intercensal change in values of the ethnic homogeneity index and the intercensal change in percentage of the titular nation is important for further thinking about ethnic polarization (see Tab. 4). This correlation is greatly either positive or negative and statistically significant. On the other hand, ethnically polarizing countries showed a small and insignificant correlation. Thus a separate calculation of that correlation for each entity is necessary. Correlations that are highly positive (benefiting the titular nation) or negative (a disadvantage to the titular nation) and statistically significant result from this. Ethnic polarization is also confirmed by a correlation between the regional values of the ethnic homogeneity index and the percentage of the titular nation for each census year separately (see Tab. 5). In the case of ethnic polarization, correlation coefficients decrease at the state level. Correlation in the home entity of the state nation is proximal to 1 and growing.

Table 4 An exemplary comparison of relationships between the change in the ethnic homogeneity index and in the proportional number of the state nation in districts of Serbia, Latvia and Estonia during the 1990s

\begin{tabular}{|l|c|c|}
\hline Country; unit & Spearman's correlation & Significance \\
\hline Serbia in total & 0.23 & 0.11 \\
\hline Central Serbia \& Vojvodina together & 0.78 & $<0.001$ \\
\hline
\end{tabular}




\begin{tabular}{|l|c|c|}
\hline Kosovo & -0.90 & $<0.001$ \\
\hline Latvia & 0.50 & 0.002 \\
\hline Estonia & 0.80 & $<0.001$ \\
\hline
\end{tabular}

Source: Computation by the author from the census data provided by the statistical institutes of the countries studied

Table 5 An exemplary comparison of relationships between the ethnic homogeneity index and the proportional number of the state nation in districts of Serbia, Latvia and Estonia at the beginning and end of the 1990s

\begin{tabular}{|l|c|c|c|}
\hline Country; unit & Year & Spearman's correlation & Significance \\
\hline \multirow{3}{*}{ Serbia in total } & 1991 & 0.840 & $<0.001$ \\
\cline { 2 - 4 } & $2000 / 06$ & 0.710 & $<0.001$ \\
\hline \multirow{2}{*}{$\begin{array}{l}\text { Central Serbia } \\
\text { \& Vojvodina together }\end{array}$} & 1991 & 0.997 & $<0.001$ \\
\cline { 2 - 4 } & 2002 & 1.000 & $<0.001$ \\
\hline \multirow{3}{*}{ Kosovo } & 1991 & -0.700 & 0.090 \\
\cline { 2 - 4 } & $2000 / 06$ & -0.300 & 0.310 \\
\hline \multirow{3}{*}{ Latvia } & 1989 & 0.960 & $<0.001$ \\
\cline { 2 - 4 } & 2000 & 0.990 & $<0.001$ \\
\hline \multirow{2}{*}{ Estonia } & 1989 & 0.830 & $<0.001$ \\
\cline { 2 - 4 } & 2000 & 0.890 & $<0.001$ \\
\hline
\end{tabular}

Source: Computation by the author from the census data provided by the statistical institutes of the countries studied

Besides ethnically polarized countries, Latvia and Estonia also demonstrated growth of the entropy index. But tables 4 and 5 show that the Baltics did not experience ethnic polarization during the 1990s. The change in the level of ethnic homogeneity and the change in the percentage of titular (state) nation strongly correlate in Latvian and Estonian districts. Moreover, the correlation between the values of the ethnic homogeneity index and the percentage of the titular (state) nation grew during the intercensal era. Therefore those two countries proved that ethnic homogenization benefited the titular (state) nations. But this process has some peculiarities there caused by its territorially uneven speed. The reason for this is the significant Russian colonization in cities and near the borders with Russia. The Russians frequently form majorities in those districts, but their absolute as well as relative numbers have been dropping, to the benefit of the Estonians and Latvians. However, change in the ethnic composition is slower in those districts in comparison with the rest of those states. The increase in the regional disorderliness of Latvia's and Estonia's ethnic composition is merely a transitional process, which will last until absolute Latvian or Estonian majorities can be formed in all large cities and borderlands. In addition to the Baltics, Croatia, Romania and the Ukraine also showed genuine ethnic homogenization (see Fig. 3). 
An appraisal of the ethnic processes in Russia is more difficult in comparison with the other examined states. Russia (its European part as well as the whole state) showed a decline in ethnic homogeneity during the 1990s. The general causes of this are the demographic crisis of the Russian nation (as well as other Christian nations of Russia), the relative demographic vigour of Russia's Muslim nations, and immigration from other post-Soviet republics which have suffered from economic slumps and armed conflicts. But a regional view reveals additional hidden trends, like a statistically significant negative relationship of federal subjects to the starting level of ethnic homogeneity, and its change during the intercensal era 1989-2002 (see Fig. 1). Subjects with a higher starting level of ethnic homogeneity achieved a lower degree of ethnic homogenization or even heterogenization. Subjects in the Northwest federal district are the former case, while Central Russia is the latter case. On the other hand, ethnically heterogeneous subjects demonstrated a higher increase in their level of ethnic homogeneity. Ethnic republics are the case; however, there are many contrasts. According to residual analysis, republics stricken by war (Chechnya-Ingushetia) are positive exceptions. The ethnic subjects with the Russian majority (Adygea, Bashkortostan, Karachay-Cherkessia, Nenetsia) are negative exceptions. But their level of ethnic homogeneity is changing, to the benefit of the titular nation. Although the republics in the Volga river basin do not disrupt that relationship (excluding Bashkortostan), different ethnic processes are in motion in them. Therefore, focusing attention on the relationship between the change in ethnic homogeneity and the change in the relative numbers of the titular nation in its unit is indispensable. The outcome is statistically insignificant and has poor positive interdependence. A greater increase in the level of ethnic homogeneity of the ethnic unit could imply a higher increase in the percentage of its titular nation (see Fig. 2). Only 6 ethnic units out of 17 showed a decrease in the proportion of their titular nation during the intercensal era. The Christian nations of the Volga river basin, Karelians and Komi-Permyaks were in this group. The Muslim nations of the Caucasus demonstrated, to the contrary, high relative as well as absolute growth. Figures 2 and 3 distinguish four types of ethnic processes:

a) ethnic homogenization for the benefit of the titular nation (Tatarstan, Caucasian republics except for Adygea and Karachay-Cherkessia),

b) ethnic heterogenization for the benefit of the titular nation, i.e. growth in the proportion of the titular nation and drop in the Russian majority (Adygea, KarachayCherkessia, Bashkortostan, Nenetsia),

c) ethnic homogenization to the disadvantage of the titular nation, i.e. strengthening of Russian dominance (Udmurtia, Karelia, Komi),

d) ethnic heterogenization to the disadvantage of the titular nation, i.e. weakening of the titular nation's dominance thanks to immigration from non-titular nations (Mari El, Mordvinia, Chuvashia). 


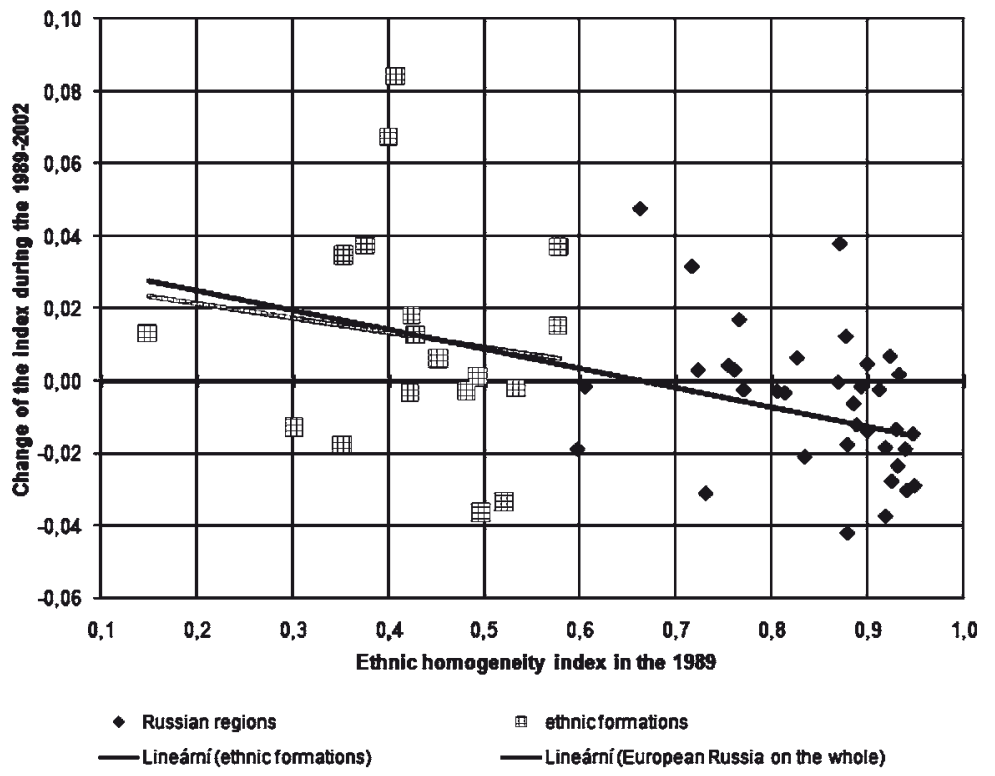

Fig. 1 Initial level of ethnic homogeneity in the European subjects of Russia in 1989 and its change during the intercensal era 1989-2002

Sources: Computation by the author from the census data provided by Norsk Utenrikspolitisk Institutt and Federal State Statistics Service

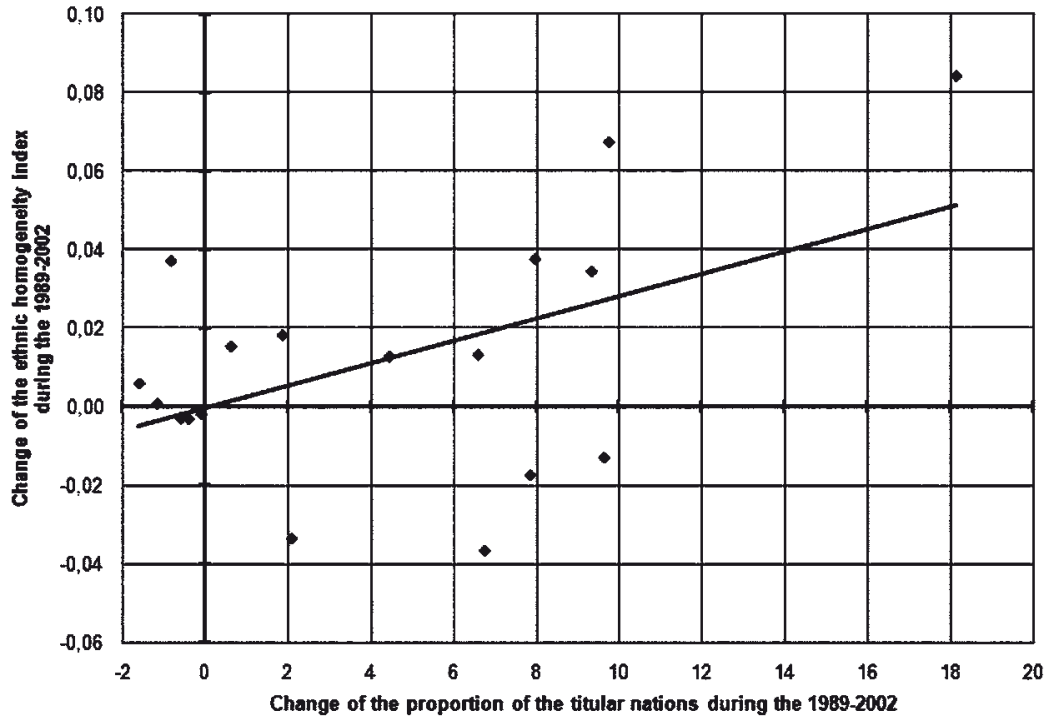

Fig. 2 Relationship between the change in the level of ethnic homogeneity and the change in the proportional size of the titular nation in the ethnic formations of Russia during the intercensal era 1989-2002

Sources: Computation by the author from the census data provided by Norsk Utenrikspolitisk Institutt and Federal State Statistics Service 
The dominance of processes a) and b) caused strengthening of the relationship between the ethnic homogeneity of the ethnic unit and the proportion of the titular nation during the intercensal era (in $1989 r=-0.47$; in $2002 r=-0.31$ ). The interconnections between the higher level of ethnic homogeneity of the ethnic unit, the lower proportion of its titular nation and the higher proportion of Russians gradually cease to be valid.

The ethnic polarization of Russia is supported not only by ethnic processes in the republics but also by processes in the Russian subjects. The latter could be divided into two groups. In spite of their depopulation, subjects in the north of the European part of Russia showed ethnic homogenization to the benefit of the Russians, owing to the emigration of the Ukrainians and Byelorussians. They were afraid of losing the opportunity to obtain their republic's citizenship (Zayonchkovskaya 2000). A very faint level of ethnic homogenization to the benefit of the Russians was also recorded by several Russian subjects in the Volga river basin. Russian immigration from Tatarstan and Bashkortostan is the reason, due to the separatist tendencies of those republics at the beginning of the 1990s. Simultaneously, some members of the nonRussian nations migrated into their ethnic republics or to adjacent Kazakhstan. Other Russian subjects (especially those in Central Russia) registered a decline in their level of ethnic homogeneity, to the disadvantage of the Russians.

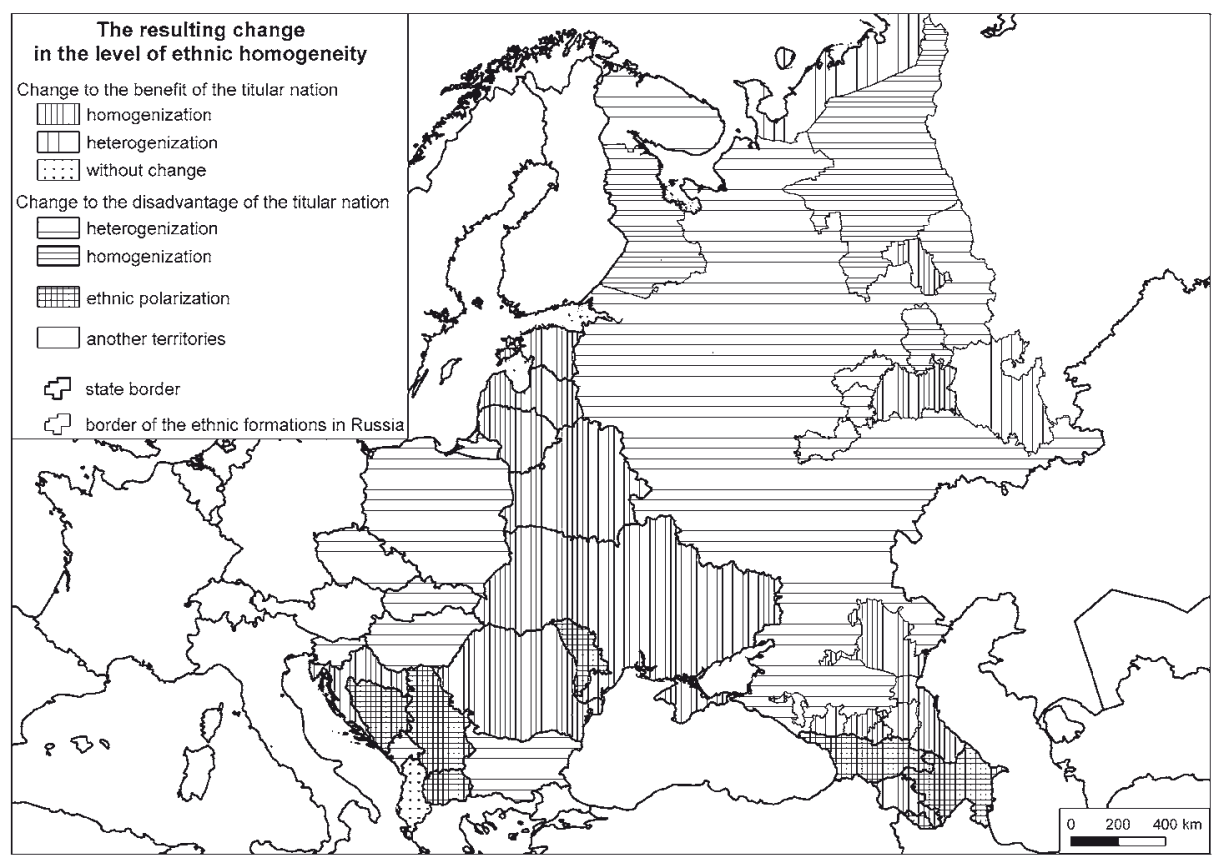

Fig. 3 Ethnic processes that occurred in post-communist Europe during the 1990s Note: In case of Romania the era 1977-2002 under study 
Here it is appropriate to answer the question whether the ethnic homogenization of the periphery is more powerful than the homogenization of the centre. A higher number of ethnic conflicts were anticipated at the periphery, and that prediction was fulfilled. A higher level of ethnic homogenization on the periphery was shown by 8 countries out of 16 examined. However, it is worth knowing that the ethnic composition of the periphery frequently changed to the titular nation's disadvantage, i.e. to the benefit of the minorities (Croats in Herzegovina, Serbs in the Republika Srpska, Albanians in Western Macedonia, East Slavs in Transnistria, Armenians in Nagorno-Karabakh, Ossetians in South Ossetia, Abkhazs in Abkhazia). In many cases of ethnically polarized countries, one periphery homogenized for the benefit of the state nation, while the other did so for the benefit of the minority. Serbization of Sandžak vs. albanization of Kosovo, or russianization of the north of European Russia vs. strengthening of the Muslim nations of the Caucasus and the Volga basin are convenient models. Stronger ethnic homogenization of the peripheries solely to the benefit of the state nation appertained only to Croatia (Krajina, Slavonia) and Romania (Transylvania). In comparison to the rest of the state's territory, other ethnically homogenizing countries showed slower ethnic homogenization of the periphery (the Eastern Ukraine, Latgale, Ida-Virumaa), to the benefit of the state nation.

The hypothesis of a higher starting level of ethnic homogeneity at the state centres was fulfilled. In that regard, centres were homogenizing at a much lower speed in comparison with the rest of the state. Bosnia-Herzegovina, the Baltics and Macedonia were exceptions because of the intermingling of their core areas. The ethnic homogeneity of centres changed for the benefit of the titular nations in the case of the Baltics and Bosnia-Herzegovina. On the other hand, it is hard to specify the obvious trend in case of Macedonia's core area. Centres of the ethnically heterogenizing countries (Slovakia, Bulgaria) showed a lower level of ethnic heterogenization in comparison with the rest of the state. More intense ethnic heterogenization on their periphery is the cause of this. Slovenia demonstrated territorially quite an even level of ethnic heterogenization. Russia is the remarkable exception because of the phenomenal level of ethnic heterogenization of Central Russia in the 1990s.

\section{Conclusion}

Many ethnic processes occurred in the post-communist countries in the 1990s. These processes were the results of governmental reactions to the multi-ethnicity of their countries. These reactions were peaceful as well as forcible. We could further distinguish between confrontational and non-confrontational peaceful reactions. The former reactions include a guarantee of minority rights (Bulgaria, Romania, Slovakia after 1998), re-federalization (Russia), granting of autonomy (Ukrainian Crimea) and assimilation of minority into majority populations (the Ukraine). The latter reactions were selective citizenship (Latvia, Estonia), deletion of undesirable people from registries (Slovenia) and nationalistic policies against minorities (Slovakia until 1998). However, caution against the unreasonable claims of minorities (e.g. Macedonia's Albanians) supported by human-rightists is necessary (Ozolins 2003). Ethnic cleansing 
stands out among the forcible instruments, however a deepening of ethnic polarization has been the outcome (e.g. Bosnia-Herzegovina, Serbia, Georgia, Azerbaijan). Hence ethnic polarization was a prevalent outcome in the 1990s. Ethnically cleansed territories are a great challenge to current regional development. Titular nations are unable to fully inhabit those territories, thanks to their low demographic vigour. Moreover, socio-economic relations are disrupted there. Some cleansed territories are separatist states (e.g. Kosovo, Abkhazia, Nagorno-Karabakh). But those entities are economically lifeless in this epoch of globalization owing to their small population and disreputable economy. Nevertheless, separatist elites do not want to re-integrate such entities into their mother states. Thus the life of separatist states is dependent on the wider geopolitical and geo-economic situation, and on their protectors.

The ethnic topic is relevant not only for the post-communist regions but also for Western Europe. Members of the Western European nations are irritated by mass immigration from other civilizations and by a failure of multiculturalism. The weak demographic vigour of the Europeans is another important variable, especially in relation to Muslim immigrants. They create large minorities and compact settlements in cities, which is connected with cultural and religious competition. Groping towards the next direction of European integration is also potentially problematic. Some Europeans are afraid a loss of national identity. That could be used by the national elites. A question for speculation could be asked at the closing of this paper: would the potential troubles of European integration replicate the Soviet or Yugoslav scenario?

\section{References}

ARENDTOVÁ, H. (1996): Původ totalitarismu I-III. OIKOYMENH, Praha, 679 p.

CONNOR, W. (1994): Ethnonationalism. The Quest for Understanding. Princeton University Press, Princeton, $234 \mathrm{p}$.

DOSTÁL, P. (1993): Ethnonationalism in the Former Soviet Union and Successor Regimes Juggling with Options. In: O’Loughlin, J., Wusten, H. van der (Eds.): New Political Geography of Eastern Europe. Belhaven Press, London, pp. 89-114.

DOSTÁL, P. (1998): The Czech-Slovak Division: Lessons of an Unsuccessful Federal State-Building. Conference on the Nation Building and the State Building in Post-Soviet Geopolitical Space. Institute of Geography of the Russian Academy of Sciences and the Open Society Institute, Moscow, 38 p.

FŇUKAL, M. (2001): Politickogeografické souvislosti jugoslávské krize. Geografie - Sborník České geografické společnosti 106 (3), Česká geografická společnost, Praha, pp. 133-147.

FUKUYAMA, F. (2002): Konec dějin a poslední člověk. Rybka Publishers, Praha, 379 p.

GELLNER, A. (1993): Národy a nacionalismus. Hř́íbal, Praha, 160 p.

HARVEY, F. P. (2000): Primordialism, Evolutionary Theory and Ethnic Violence in the Balkans: Opportunities and Contrasts for Theory and Policy. Canadian Journal of Political Science 33 (1), Canadian Political Science Association, Ottawa, pp. 37-65.

HROCH, M. (1996): Nationalism and National Movements: Comparing the Past and the Present of Central and Eastern Europe. Nations and Nationalism 2 (1), Blackwell Publishers, Oxford and Malden, pp. $35-44$.

HUNTINGTON, S. P. (2001): Střet civilizací. Boj kultur a proměna světového řádu. Rybka Publishers, Praha, $441 \mathrm{p}$.

JOHNSON, N. C. (2002): The Renaissance of Nationalism. In: Johnston, R. J., Taylor, P. J., Watts, M. J. (Eds.): Geography and Global Change. Remapping the World. Blackwell Publishing, Oxford and Malden, pp. 130-142. 
KELMAN, H. C. (1997): Negotiating National Identity and Self-Determination in Ethnic Conflicts: The Choice Between Pluralism and Ethnic Cleansing. Negotiation Journal 13 (4), Springer Netherlands, Rotterdam, pp. 327-340.

KREJČÍ, J. (2002): Postižitelné proudy dějin. Sociologické nakladatelství, Praha, 563 p.

MACFARLANE, N. S. (1997): Democratization, Nationalism and Regional Security in the Southern Caucasus. Government and Opposition 32 (3), Blackwell Publishers, Oxford and Malden, pp. 399-420.

MALEK, M. (2006): State Failure in the South Caucasus: Proposals for an Analytical Framework. Transition Studies Review 13 (2), Springer-Verlag, Wien, pp. 441-460.

MASSEY, D. S., DENTON, N. A. (1988): The Dimensions of Residential Segregation. Social Forces 67 (2), University of North Carolina Press, Chapel Hill, pp. 281-315.

NEDERVEEN PIETERSE, J. (1997): Deconstructing/Reconstructing Ethnicity. Nations and Nationalism 3 (3), Blackwell Publishers, Oxford and Malden, pp. 365-395.

OZOLINS, U. (2003): The Impact of European Accession upon Language Policy in the Baltic States. Language Policy 2 (3), Kluwer Academic Publishers, Rotterdam, pp. 217-238.

PEARSON, R. (1995): The Making of '89: Nationalism and the Dissolution of Communist Eastern Europe. Nations and Nationalism 1 (1), Blackwell Publishers, Oxford and Malden, pp. 69-79.

PETTAI, V., HALLIK, K. (2002): Understanding Processes of Ethnic Control: Segmentation, Dependency and Co-optation in Post-Communist Estonia. Nations and Nationalism 8 (4), Blackwell Publishers, Oxford and Malden, pp. 505-529.

PIASECKI, E. (1964): Charakterystyka liczebności ludów świata i próba analizy zwartości etnicznej terytoriów. Czasopismo Geograficzne 35, Polskie Towarzystwo Geograficzne, Wrocław, pp. 73-85.

RADVANYI, J., MUDUYEV, S. S. (2007): Challenges Facing the Mountain Peoples of the Caucasus. Eurasian Geography and Economics 48 (2), Bellwether Publishing, Columbia, pp. 157-177.

ROWLAND, R. H. (2008): Population Trends in a Contested Pseudo-State: The Case of Nagorno-Karabakh. Eurasian Geography and Economics 49 (1), Bellwether Publishing, Columbia, pp. 99-111.

SMITH, A. D. (1998): Nationalism and Modernism. Routledge, London and New York, 270 p.

TESAŘ, F. (2007): Etnické konflikty. Portál, Praha, 251 p.

VANHANEN, T. (1999): Domestic Ethnic Conflict and Ethnic Nepotism: A Comparative Analysis. Journal of Peace Research 36 (1), Sage Publications, London, pp. 55-73.

YAMSKOV, A. N. (1991): Ethnic Conflict in the Transcaucasus. The Case of Nagorno-Karabakh. Theory and Society 20 (5), Springer Netherlands, Rotterdam, pp. 631-660.

ZAYONCHKOVSKAYA, Z. (2000): Recent Migration Trends in the Commonwealth of Independent States. International Social Science Journal 52 (165), Blackwell Publishers, Oxford and Malden, pp. 343-355.

ŽALOUDEK, K. (2004): Encyklopedie politiky. Nakladatelství Libri, Praha, pp. 110-111.

\section{Résumé}

\section{Etnické procesy v postkomunistické Evropě v 90. letech 20. století}

Článek hodnotí a vysvětluje proměny etnické struktury, jež proběhly v evropských a kavkazských postkomunistických zemích během 90. let 20. století. Důraz je kladen nejen na kvantitativní, nýbrž i na kvalitativní stránku etnodemografických proměn. Jde tedy o zhodnocení chování majority a minorit a vztahu mezi nimi, jenž byl ovlivněn rozmachem nacionalismu a separatismu. Výchozí datovou základnou jsou sčítání lidu 1989/1992 a 1999/2004, při jejich absenci pak odhady mezinárodních organizací. Hodnocení bylo prováděno na úrovni států a regionů, a to jak pomocí speciálně zkonstruovaných indexů, tak i korelace.

Současná etnická struktura postkomunistické Evropy je výsledkem tř́ etnických procesů - etnické homogenizace, polarizace i heterogenizace. Homogenizace se týkala států s nižší výchozí úrovní etnické homogenity. Hojným výsledkem byla také u řady zemí jejich etnická polarizace, tj. v rámci jednoho státu zformování dvou a více etnicky odlišných homogenních jednotek. Tyto procesy byly rychlejší ve válkou zasažených územích, a to díky násilným přesunům obyvatelstva a užívání etnického čištění. V mírových podmínkách pak důležitou roli hrají přirozený přírůstek, vládní politika ve vztahu k menšinám a atmosféra 
ve společnosti. Naopak v etnicky vysoce homogenních zemích došlo během 90 . let 20 . století k poklesu etnické homogenity, tj. k heterogenizaci. Př́ícinou byla jednak imigrace, nemalou úlohu hráli také subjektivní činitelé (proměna etnické identifikace).

Etnické konflikty jsou zejména doménou periferie, nebot' historická jádra států jsou etnicky vysoce homogenní. Rychlejší etnická homogenizace periferie ve prospěch státního národa však nebyla pravidlem. $\mathrm{K}$ rozličným etnickým procesům docházelo také $\mathrm{v}$ jádrových oblastech. Při hodnocení etnických procesů $\mathrm{v}$ rámci dichotomie jádro-periferie tedy nelze hovořit o jasných pravidelnostech.

Vladimir Vojtěch

Charles University in Prague, Faculty of Science Department of Social Geography and Regional Development Albertov 6

12843 Prague 2

Czech Republic

e-mail:vojtech@natur.cuni.cz 